\title{
ANALISIS EFEKTIVITAS DAN KONTRIBUSI PAJAK KENDERAAN BERMOTOR TERHADAP PENCAPAIAN TARGET PENDAPATAN ASLI DAERAH PROVINSI ACEH
}

\author{
Rahmatul Fitriya ${ }^{* 1}$, Suparno ${ }^{* 2}$ \\ ${ }^{1,2}$ Program Studi Akuntansi Fakultas Ekonomi dan Bisnis Universitas Syiah Kuala \\ e-mail: rahmatulfitriya93@ gmail.com ${ }^{* 1}$, suparno.feakt@ unsyiah.ac.id $^{\text {*2 }}$
}

\begin{abstract}
Motor vehicle tax is one of the most potential local taxes for Aceh province in improving local income. This research aims to discover the rate of effectiveness of motor vehicle tax acceptance and exact portion of its contribution toward the target of Aceh's local own revenues. Kind of data used in this research aresecondary data. They are collected from relevant literatures, websites, and documents which concerned on effectiveness and contribution of the acceptance of motor vehicle tax in Aceh province. The research result shows (1) the effectiveness of motor vehicle tax acceptance towards the target of local own revenues attainment has annual fluctuation which can be categorized as strongly (very) effective' from 2013-2014 and 'effective' in 2015. Whereas (2) the contribution of motor vehicle tax acceptance towards the target of local own revenues attainment constantly increase every year, yet it is categorized lack in 2013 2015.
\end{abstract}

Keywords: Efektivitas, Kontribusi, Pajak Kenderaan Bermotor (PKB), Pendapatan Asli Daerah (PAD)

\section{Pendahuluan}

\section{Latar Belakang}

Pelaksanaan pembangunan nasional diperlukan adanya pembiayaan pembangunan baikyang berasal dari penerimaan dalam negeri maupun pinjaman dari luar negeri. Pemerintah pusat tidak dapat terus menerus mengandalkan pembiayaan yang berasal dari pinjaman luar negeri. Oleh sebab itu, sumber-sumber pembiayaan yang berasal dari penerimaan dalam negeri sangat penting dikembangkan dan ditingkatkan peranannya untuk kelangsungan hidup bangsa.

Salah satu sumber penerimaan negara yang digunakan untuk melaksanakan pembangunan bagi seluruh rakyat Indonesiah adalah pajak. Pajak merupakan suatu kewajiban menyerahkan sebagian dari kekayaan ke kas negara yang disebabkan suatu keadaan, kejadian, dan perbuatan yang memberikan kedudukan tertentu, tetapi bukan sebagai hukuman, menurut peraturan yang ditetapkan pemerintah serta dapat dipaksakan, tetapi tidak ada jasa timbal balik dari negara secara langsung untuk memelihara kesejahteraan secara umum. (resmi, 2014:1)

Di Indonesia, pajak merupakan salah satu sumber dana terbesar dalam pembiayaan pembangunan yang berasal dari masyarakat. Pajak telah menjadi penggerak roda pembangunan yang sangat dominan. Masyarakat harus menyadari kewajibannya untuk turut serta berpartisipasi dalam pembangunan nasional yaitu dengan taat membayar pajak. (Mardiasmo, 2013:16).

Berdasarkan pemungutannya, pajak Indonesia dapat dikelompokkan menjadi dua yaitu pajak pusat dan pajak daerah. Pajak pusat dipungut oleh pemerintah pusat dan digunakan untuk membiayai rumah tangga negara pada umumnya. Pajak pusat terdiri dari PPh, PPN, dan PPnBM, serta Bea Perolehan Hak atas Tanah dan Bangunan (BPHTB). Pajak daerah dipungut oleh pemerintah daerahbaik daerah tingkat I (pajak Provinsi) maupun daerah tingkat II (Pajak Kabupaten/Kota) dan digunakan untuk membiayai rumah tangga masingmasing.

Menurut undang- undang Nomor 28 Tahun 2009 tentang Pajak Derah dan Restribusi Daerah, jenis-jenis pajak provinsi ditetapkan sebanyak 5 (lima) jenis yaitu Pajak Kenderaan Bermotor (PKB), Bea Balik Nama Kenderaan Bermotor (BBNKB), Pajak Air Permukaan, dan Pajak Rokok. Setiap provinsi atau daerah diijinkan untuk tidak memungut salah satu atau beberapa jenis pajak yang telah ditetapkan apabila potensi pajak di daerah atau provinsi tersebut dipandang kurang memadai. Meskipun beberapa jenis 
pajak daerah dan restribusi daerah sudah ditetapkan dengan undang-undang ini, daerah kabupaten/kota diberikan peluang menggali potensi sumber-sumber keuangan dengan menetapkan jenis pajak dan restribusi selain yang telah ditetapkan, sepanjang memenuhi kriteria yang ditetapkan dan sesuai dengan aspirasi masyarakat.

Undang-undang Nomor 32 Tahun 2014 tentang Pemerintahan Daerah dan Undang-undang Nomor 33 Tahun 2004 tentang Perimbangan Keuangan antara Pemerintah Pusat dan Pemerintah Daerah, memberikan perubahan dalam pengelolaan keuangan daerah sehingga terjadi reformasi dalam manajemen keuangan daerah. Selain perubahan terhadap sistem pengelolaan keuangan daerah, kedua undang-undang tersebut merubah akuntabilitas pemerintah daerah dari pertanggungjawaban vertikal (kepada pemerintah pusat) ke pertanggungjawaban horizontal (kepada masyarakat melalui DPRD).

Semakin tinggi peran pendapatan asli daerah dalam anggaran pendapatan dan belanja daerah, mencerminkan keberhasilan usaha atau tingkat kemampuan daerah dalam pembiayaan dan penyelenggaraan pengembangan serta pemerintah. Dengan demikian, apabila Pendapatan Asli Daerah meningkat dari tahun ketahun dana dari pusat dan juga daerah bisa lebih leluasa dalam membelanjakan penerimaan mereka sesuai dengan perioritas pembangunan yang ada didaerah. (Badan Pengelolaan Keuangan Aceh)

Penelitian yang dilakukan oleh Hasannudin dan Heice R (2013) Analisis Efektivitas dan Kontribusi Pajak Kenderaan Bermotor Terhadap Penerimaan Pendapatan Asli Daerah di Provinsi Maluku Utara. Hasilnya menunjukkan bahwa Penerimaan pajak kenderaan bermotor di Provinsi Maluku Utara sudah efektif, walaupun dari tahun ketahun menunjukkan kecenderungan menurun akibat dari adanya perbedaan antara kenaikan target dengan realisasinya, sementara kontribusi pajak kenderaan bermotor terhadap pendapatan asli daerah menunjukkan kurangnya keseriusan dalam mengidentifiasi , dan mengoptimalkan sejumlah objek pajak yang menjadi objek pajak kenderaan bermotor, dan pertumbuhannya cenderung menurun dari tahun ketahun.

\section{Tujuan Penelitian}

1. Untuk mengetahui tingkat efektivitas pajak kenderaan bermotor terhadap pencapain target Pendapatan Asli Daerah Provinsi Aceh.

2. Untuk mengetahui seberapa besar kontribusi pajak kenderaan bermotor terhadap pencapaian target Pendapatan Asli Daerah.

\section{Kajian Pustaka}

\section{Pendapatan Asli Daerah}

Pendapatan asli daerah menurut UndangUndang No. 28 Tahun 2009 yaitu pendapatan yang diperolah daerah yang dipungut berdasarkan peraturan daerah sesuai dengan perundang-undangan, bahwa pendapatan asli daerah bersumber dari hasil pajak daerah, hasil restribusi daerah, hasil pengelolaan kekayaan daerah yang dipisahkan dan lain-lain pendapatan asli daerah yang sah.

\section{Pajak Daerah}

Menurut (Resmi 2014: 8) Pajak daerah yaitu pajak yang dipungut oleh pemerintah daerah baik daerah tingkat I (Pajak Provinsi) maupun pajak daerah tingkat II (Pajak Kabupaten/kota) dan digunakan untuk membiayai rumah tangga daerah masing-masing. Pajak Daerah di Indonesia berdasarkan UndangUndang No.34 Tahun 2009 terbagi menjadi dua yaitu Pajak Provinsi dan Pajak Kabupaten/Kota. Pembagian ini dilakukan sesuai dengan kewenangan pengenaan dan pemungutan masing-masing jenis pajak daerah pada wilah administrasi provinsi atau kabupaten/kota yang bersangkutan.

\section{Pengertian Pajak Kenderaan Bermotor}

Qanun Nomor 2 tahun 2012 tentang Pajak Aceh menyebutkan bahwa kenderaan bermotor adalah semua kendaraan beroda beserta gandengannya yang digunakan di semua jenis jalan darat, dan digerakkan oleh peralatan teknik berupa motor atau peralatan lainnya yang berfungsi untuk mengubah suatu sumber daya energi tertentu menjadi tenaga gerak kendaraan bermotor yang bersangkutan, termasuk alat -alat berat dan alat-alat besar yang dalam operasinya menggunakan roda dan motor dan tidak melekat secara permanen serta kendaraan bermotor yang dioperasikan di air.

\section{Objek Pajak Kendaraan Bermotor}

Pasal 4 ayat (1) dalam Qanun Aceh Nomor 2 Tahun 2012 ini disebutkan bahwa objek Pajak 
Kenderaan Bermotor adalah kepemilikan dan/atau penguasaan kenderaan bermotor. Kemudian dalam ayat (3) disebutkan bahwa dikecualikan dari Objek PKB adalah:
a. Kereta Api
b. Kenderaan bermotor yang semata-mata digunakan untuk keperluan pertahanan dan keamanan negara
c. Kenderaan bermotor yang dimiliki dan/atau dikuasai kedutaan, konsultan perwakilan negara asing dengan azaz timbal balik dan lembaga- lembaga internasional yang memperoleh fasilitas pembebasan pajak dari pemerintah
d. Pabrikan atau importir yang semata-mata tersedia untuk dipamerkan dijual, dan
e. Kenderaan bermotor yang disegel atau disita oleh negara.

\section{Subjek Pajak Kendaraan Bermotor}

Pada pasal 5 ayat (1) Qanun Aceh Nomor 2 Tahun 2012 ini, menyebutkan bahwa subjek Pajak Kenderaan Bermotor adalah orang pribadi atau badan yang memiliki dan/atau menguasai kenderaan bermotor. Oleh karenanya dalam ayat (2) disebutkan bahwa wajib pajak kenderaan bermotor adalah orang pribadi atau badan yang memiliki kenderaan bermotor.

Subjek Pajak atas Kendaraan Bermotor adalah (Pasal 4 Undang-undang No 28 tahun 2009 tentang Pajak dan Retribusi Daerah) :

a. Subjek Pajak Kendaraan Bermotor adalah orang pribadi atau Badan yang memiliki dan/atau menguasai Kendaraan Bermotor.

b. Wajib Pajak Kendaraan Bermotor adalah orang pribadi atau Badan yang memiliki Kendaraan Bermotor.

c. Dalam hal Wajib Pajak Badan, kewajiban perpajakannya diwakili oleh pengurus atau kuasa Badan tersebut.

\section{Dasar Pengenaan Pajak Kendaraan Bermotor}

Dasar pengenaan Pajak Kendaraan Bermotor adalah hasil perkalian dari 2 (dua) unsur pokok (Pasal 5 Undang-Undang No 28 tahun 2009 tentang Pajak dan Retribusi Daerah) :

1. Nilai Jual Kendaraan Bermotor; dan

2. bobot yang mencerminkan secara relatif tingkat kerusakan jalan dan/atau pencemaran lingkungan akibat penggunaan Kendaraan Bermotor.
Menurut Qanun Nomor 2 tahun 2012, hasil penerimaan Pajak Kenderaan Bermotor ditetapkan pembagiannya sebagai berikut:

1. bagian Provinsi sebesar 70\% (tujuh puluh persen), dan

2. bagian Kabupaten/Kota sebesar 30\% (tiga puluh persen).

Selanjutnya didalam Qanun tersebut dijelaskan bahwa bagian penerimaan kabupaten/kota setelah dibulatkan $100 \%$ (seratus persen) dibagi kepada kabupaten/kota dalam Provinsi sebagai berikut:

1. $50 \%$ (lima puluh persen) dibagi berdasarkan potensi/realisasi penerimaan Pajak Kenderaan Bermotor untuk masing-masing Kabupaten/Kota yang bersangkutan, dan

2. $50 \%$ (lima puluh persen) dibagi rata, kepada seluruh Kabupaten/Kota.

\section{Efektivitas}

Menurut Halim (2004 : 166)menyatakn bahwa efektivitas harus dinilai atas tujuan yang bisa dilaksanakan dan bukan atas konsep tujuan yang maksimum. Jadi efektivitas adalah ukuran seberapa jauh organisasi berhasil mencapai tujuan yang layak dicapai. Apabila dikaitkan dengan pemungutan pajak atas kenderaan bermotor, maka efektivitas yang dimaksut adalah seberapa besar realisasi penerimaan pajak atas kenderaan bermotor berhasil mencapai potensi dan atau target yang seharusnya dicapai pada suatu periode tertentu.

\section{Kontribusi}

Menurut Mahmudi (2010:145) kontribusi adalahsesuatu yang diberikan bersama-sama dengan pihak lain untuk tujuan biaya atau kerugian tertentu atau bersama. Jadi kontribusi yang dimaksud dapat diartikan sebagai sumbangan yang diberikan oleh pendapatan pajak atas kenderaan bermotor terhadap Pendapatan Asli Daerah. Jika potensi penerimaan pajak kenderaan bermotor semakin besar dan pemerintah daerah dapat mengoptimalkan sumber penerimaannya maka akan memberikan peluang kepada peningkatan Pendapatan Asli Daerah.

\section{Penelitian Terdahulu}

Menurut Rompis (2015) menyimpulkan hasil penelitiannya menunjukkan bahwa jumlah penerimaan pajak kenderaan bermotor selama tahun 2011-2014 
memberikan kontribusi yang cukup besar setiap tahunnya sehingga hal ini mempengaruhi jumlah PAD yang diterima Provinsi Sulawesi Utara.

Mokoginta (2015) melalui penelitiannya menunjukkan bahwa prosedur pemungutan pajak kenderaan bermotor dan bea balik nama kenderaan bermotor sudang efektif, begitun dengan penerimaan pajaknya, sedangkan kontribusi terhadap pendapatan asli daerah (PAD). Sari (2013) melalui penelitiaanya bahwa pajak kenderaan bermotor dan bea balik nama kenderaan bermotor berpengaruh terhada PAD. Hal ini dikarenakan pencapaian realisasi dari PKB dan BBNKB pada tahun anggaran 2009-2012 selalu melihat target.

\section{METODE PENELITIAN}

\section{Jenis Penelitian}

Penelitian ini merupakan penelitian deskriptif kuantitatif. Data yang digunakan yaitu data target dan realisasi pajak kendaraan bermotor Provinsi Aceh tahun anggaran 2013 sampai 2015. Menurut Sekaran (2013:4) mengemukakan "metode penelitian deskriptif kuantitatif merupakan penelitian empiris dimana data adalah dalam bentuk sesuatu yang dapat dihitung/angka." Penelitian deskriptif kuantitatif memerhatikan pada pengumpulan dan analisis data dalam bentuk numerik.

\section{Tempat Penelitian}

Penelitian ini dilaksanakan pada Kantor Badan Pengelolaan Keuangan Aceh (DPKA).

\section{Sumber dan Jenis Data}

Data dalam penelitian ini adalah data sekunder. Data yang digunakan data target dan realisasi pajak kendaraan bermotor serta jumlah kenderaan bermotor Provinsi Aceh tahun anggaran 2013 sampai 2015. Menurut Sugiyono (2010:13), data sekunder mengacu kepada data yang dikumpulkan dengan metode dokumentasi. Ini dilakukan dengan cara mengumpulkan, mencatat dan mengitung data-data yang berhubungan denga peneliti.

\section{Teknik Pengumpulan Data}

Teknik yang digunakan dalam pengumpulan data dengan cara dokumentasi. Menurut Sugiono (2008:82) dokumentasi merupakan catatan peristiwa yang sudah berlalu. Dokumen bisa berbentuk tulisan, gambar, atau karya-karya monumental dari seseorang. Dokumen yang dimaksud dalam penelitian ini adalah buku laporan realisasi anggaran Badan Pengelolaan Keuangan Aceh. (BPKA)

\section{Metode Analisis Data}

\section{Analisis Efektivitas}

Untuk mengetahui efektivitas penerimaan PKB terhadap pendapatan asli daerah dapat dilakukan dengan menghitung perbandingan antara penerimaan dan potensi Pajak Kenderaan Bermotor pada tahun 2013-2015. Realisasi penerimaan Pajak Kendaraan Bermotor, diperoleh dari seluruh jumlah pajak kendaraan bermotor yang diperoleh dari tiap Samsat yang ada di kabupaten/kota di Provinsi Aceh. Efektivitas dapat diukur dengan rumus sebagai berikut (Rima,2012)

\section{Efektifitas PKB $=\quad \underline{\text { Realisasi penerimaan }}$ $\underline{\text { PKB }} \times 100 \%$}

\section{Target penerimaan PKB}

Guna untuk mengukur tingkat efektivitas maka digunakan indikator pada tabel 3.1 dibawah ini:

Tabel 3.1

Interprestasi Nilai Efektifitas

\begin{tabular}{|c|c|}
\hline Persentase & Kriteria \\
\hline$>100 \%$ & Sangat efektif \\
\hline $90-100 \%$ & Efektif \\
\hline $80-90 \%$ & Cukup \\
\hline $60-80 \%$ & Kurang efektif \\
\hline$<60 \%$ & Tidak efektif \\
\hline
\end{tabular}

Sumber: Depdagri, kepmendagri No. 690.900.327 (Rima Adelina,2012)

\section{Analisis Kontribusi}

Menurut (Gurtitno 1997:49) kontribusi merupakansesuatu yang diberikan bersama - sama dengan pihak lain untuk tujuan biaya atau kerugian tertentu. Sehingga dalam penelitian ini kontribusi yang dimaksud dapat diartikan sebagai sumbangan yang diberikan oleh pendapatan Pajak atas Kendaraan Bemotor terhadap Pendapatan Asli Daerah, digunakan rumus sebagai berikut (velayati at al:2013)

Kontribusi PKB $=\quad$ Realisasi PKB $\times 100 \%$

Realisasi penerimaan PAD

Penilaian kinerja rasio kontribusi dapat dilihat pada 
Tabel 3.2

Tabel 3.2

Klasifikasi kriteria kontribusi

\begin{tabular}{|c|c|}
\hline Persentase & Kriteria \\
\hline $0,00 \%-10 \%$ & Sangat Kurang \\
\hline $10,10 \%-20 \%$ & Kurang \\
\hline $20,10 \%-30 \%$ & Sedang \\
\hline $30,10 \%-40 \%$ & Cukup Baik \\
\hline $40,10 \%-50 \%$ & Baik \\
\hline
\end{tabular}

\section{$>50 \%$ \\ Sangat Baik}

Sumber: Depdagri, kepmendagri No. 690.900.327 (Velayati at al, 2013)

\section{Hasil Penelitian}

\section{Efektivitas Penerimaan PKB}

Berdasarkan data yang diperoleh, hasil presentase efektivitas penerimaan PKB di provinsi aceh secara keseluruhan dapat dilihat pada tabel 4.2

Tabel 4.2

Target dan Realisasi penerimaan pajak kenderaan bermotor Provinsi Aceh Tahun 2013-2015

\begin{tabular}{|c|c|c|c|c|}
\hline Tahun & Target PKB & Realisasi PKB & Persentase & Kriteria \\
\hline 2013 & $\mathbf{2 2 1 . 9 6 9 . 6 5 1 . 1 7 7}$ & $\mathbf{2 5 8 . 0 1 9 . 7 4 2 . 8 5 1}$ & $\mathbf{1 1 6 , 2 4} \%$ & Sangat efektif \\
\hline 2014 & $\mathbf{2 5 8 . 3 7 6 . 8 4 2 . 9 2 2}$ & $\mathbf{2 7 9 . 0 7 2 . 9 9 3 . 4 6 3}$ & $\mathbf{1 0 8 , 0 1 \%}$ & Sangat efektif \\
\hline 2015 & $\mathbf{3 3 2 . 0 9 5 . 0 2 1 , 1 3 9}$ & $\mathbf{3 0 2 . 5 3 0 . 8 9 7 . 1 0 2}$ & $\mathbf{9 1 , 0 7} \%$ & Efektif \\
\hline \multicolumn{2}{|c|}{ Rata - rata } & $105.10 \%$ & Sangat Efektif \\
\hline
\end{tabular}

Sumber: Data diolah (2016)

Berdasarkan tabel 4.2 diatas tingkat efektivitas penerimaan pajak kenderaan bermotor rata-rata dari tahun 2013-2015 adalah sebesar 105.10 berdasarkan pada kriteria dalam persentase tersebut adalah sangat efektif.Hal ini menunjukkan bahwa Pemerintah Daerah Provinsi Aceh dalam hal ini Badan
Pengelolaan Keuangan Aceh dinilai sangat baik dalam mengelola penerimaan pajak kenderaan bermotor.

\section{Kontribusi Penerimaan PKB}

Besarnya kontribusi penerimaan PKB terhadap pendapatan asli daerah di provinsi aceh selengkapnya dapat dilihat pada tabel 4.3

Tabel 4.3

Kontribusi Pajak Kenderaan Bermotor pada PAD di Provinsi Aceh Tahun 2013-2015

\begin{tabular}{|c|c|c|c|c|}
\hline Tahun & Realisasi PKB (Rp) & Realisasi PAD (Rp) & Persentase & Kriteria \\
\hline 2013 & 258.019.742.851 & 1.396.095.430.738 & $18,48 \%$ & Kurang \\
\hline 2014 & 279.072.993.463 & 1.779.626.321.281 & $15,68 \%$ & Kurang \\
\hline 2015 & 302.530.897.102 & 1.914.345.718.874 & $15,80 \%$ & Kurang \\
\hline \multicolumn{3}{|c|}{ Rata - rata } & $16.65 \%$ & Kurang \\
\hline
\end{tabular}

Sumber: Data diolah (2016)

Berdasarkan tabel 4.3 diatas kontribusi pajak kenderaan bermotor terhadap Pendapatan Asli Daerah rata-rata dari tahun 2013-2015 adalah sebesar $16.65 \%$, jika berdasarkan pada kriteria atau indikator tersebut diatas maka penilaiannya adalah kurang baik. Ini menunjukkan bahwa Pemerintah Daerah Provinsi Aceh dalam hal ini Badan Pengelolaan Keuangan Aceh kurang dalam mengidentifikasi, dan mengoptimalkan sumber-sumber penerimaan yang tergolong dalam objek pajak kenderaan bermotor, sehingga kontribusinya terhadap PAD kurang memuaskan.

\section{Kesimpulan}

Kesimpulan 
Berdasarkan hasil penelitian dan analisis data yang telah dijelaskan sebelumnya, maka dapat disimpulkan beberapa hal sebagai berikut :

1. Efektivitas penerimaan Pajak Kenderaan Bermotor di Provinsi Aceh adalah sangat efektif dengan perolehan rata-rata persentase sebesar $105,10 \%$. Hal ini menunjukkan bahwa Pemerintah Daerah Provinsi Aceh dalam hal ini Badan Pengelolaan Keuangan Aceh dinilai sangat baik dalam mengelola penerimaan pajak kenderaan bermotor.

2. Kontribusi pajak kenderaan bermotor terhadap pendapatan asli daerah Provinsi Aceh adalah kurang, dengan perolehan rata-rata persentase sebesar 16,65\%. Ini menunjukkan bahwa Pemerintah Daerah Provinsi Aceh dalam hal ini Badan Pengelolaan Keuangan Aceh kurang dalam mengidentifikasi, dan mengoptimalkan sumbersumber penerimaan yang tergolong dalam objek pajak kenderaan bermotor, sehingga kontribusinya terhadap PAD kurang memuaskan.

\section{Saran}

Sehubungan dengan hasil penelitian yang diperoleh, maka dapat ditemukan beberapa sana sebagai berikut :

1. Untuk meningkatkan tingkat efektivitas pajak kenderaan bermotor di Provinsi Aceh, maka diharapkan kepada pemerintah melalui pihak terkait agar dapat memberikan pelayanan terbaik bagi wajib pajak dengan tetap meningkatkan sosialisai, melakukan upaya peningkatan pelayanan dengan menggunakan SAMSAT keliling dan memberikan kemudahan kepada wajib pajak untuk membayar PKB secara online.

2. Kepada pihak yang terkait dalam Qanun No 12 Tahun 2012 tentang Pajak Aceh dalam hal Pajak Kenderaan Bermotor, agar menurunkan tarif Pajak Kenderaan Bermotor sehingga dalam penerimaan realisasi PKB sesuai dengan target yang telah ditentukan.

3. Bagi peneliti selanjutnya diharapkan dapat melakukan penelitian yang lebih luas, mengingat masih ada faktor lain yang dapat mempengaruhi pencapaian target terhadap pendapatan asli daerah dengan persentase yang cukup besar, maka didiharapkan peneliti selanjutnya untuk dapat menggali spesifikasi potensi pencapaian target terhadap pendapatan asli daerah dari pajak kenderaan bermotor sehingga benar-benar dapat memberikan hasil penelitian yang lebih kuat dan memuaskan.

\section{Daftar Pustaka}

Adelina, Rima. 2012. Analisis Efektivitas dan Kontribusi Penerimaan Pajak Bumi dan Bangunan (PBB) terhadap Pendapatan Daerah diKabupaten Gresik. Universitas Negeri Surabaya. Skripsi.

Asih, Woro Wiryaningtyas. 2009. Pelaksanaan Pemungutan Pajak Kenderaan Bermotor Di Unit Pelayanan Pendapatan dan Pembayaran Aset Daerah (UP3AD) Kabupaten Pemalang. Universitas Diponegoro. Semarang.

Badan Pusat Satistik. 2016. Provinsi Aceh Dalam Angka.

Darise, Nurlan. 2009. Pengelolaan Keuangan Daerah. Cetakan 1. PT. Macan Jaya Cemerlang, Jakarta.

Dinas Pendapatan dan Kekayaan Aceh 2016. Provinsi Aceh

Guritno, T. 1997. Kamus Ekonomi-bisnis-perbankan : Inggris-Indonesia.Gajah Mada University Press, Yogyakarta

Halim, Abdul. 2007. Akuntansi Keuangan Daerah. Salemba Empat, Jakarta.

Hasanuddin dan Wokas, Heince, R, N. (2013) Analisis Efektivitas dan Kontribusi Pajak Kenderaan Bermotor Terhadap Penerimaan Pendapatan Asli Daerah Di Provinsi Maluku Utara. Jurnal Universitas Sam Ratulangi, Manado.

Karina, Budiarsi. 2016. Analisis Efektivitas dan Kontribusi Pajak Kenderaan Bermotor Terhadap Pendapatan Asli Daerah Provinsi Gorontalo.

Mahmudi. (2010). Manajemen Kinerja Sektor Publik Jilid 2. Yogyakarta UPP Sekolah Tinggi Ilmu Manajemen YKPN.

Mardiasmo. 2103. Akuntansi Sektor Publik. Yogyakarta: Andi Publisher

Mardiasmo.2011. Perpajakan. Andi, Yogyakarta.

Marihot, Siahan. 2013. Pajak Daerah dan Restribusi Daerah. Edisi Revisi. PT. Raja Grafindo Persada, Jakarta.

Martoyo, Susilo. 1998. Manajmen Sumber Daya Manusia Adisi 3. BPFE, Yogyakarta.

Mokoginta, Nani Chairani. 2015. Analisis Efektivitas 
Prosedur Pemungutan Pajak Kenderaan Bermotor Dan Bea Balik Nama Kenderaan Bermotor Dalam Peningkatan Pendapatan Asli Daerah Provinsi Sulawesi Utara.

Nurcholis Hanif. 2012. Teori dan Praktik Pemerintahan dan Otonomi Daerah. Jakarta : PT Grasindo.

Qanun Nomor 7 tahun 2011 Tentang Pajak Daerah dan Restribusi.

Qanun Aceh Nomor 2 Tahun 2012 Tentang Pajak Aceh.

Resmi, Siti. 2014. Perpajakan Teori dan Kasus, Buku 1 edisi 8. Jakarta: Salemba empat

Rompis, Natalia Ester. 2015. Analisis Kontribusi Pajak Kenderaan Bermotor Terhadap Pendapatan Asli Daerah Provinsi Sulawesi Utara (Studi Kasus Pada Samsat Airmadidi). Jurnal Berkala Ilmiah Efesiensi. Universitas Sam Ratulangi. Manado

Rooy, Budiarso. 2015. Analisis Kontribusi Penerimaan Pajak Daerah Terhadap Pendapatan Asli Daerah Di Kabupaten Raja Ampat.

Santoso, Purbayu Budi dan Rahayu, Retno puji. Analisis Pendapatan Asli Daerah dan FaktorFaktor yang mempengaruhi Dalam Upaya Pelaksanaan Otonomi Daerah Di Kabupaten Kediri. Jurnal Dinamika Pembangunan Vol.2 No. 1, Juli 2005, Halaman 9-18

Sari, Tri Mustika. 2013. Analisis Kontribusi Pajak Kenderaan Bermotor dan Bea Balik Nama Kenderaan Bermotor Terhadap Pendapatan Asli Daerah Provinsi Jawa Tengah (Studi Kasus pada DPPAD Provinsi Jawa Tengah).

Sedarmayanti dan Hidayat Syarifudin. 2011. Metodologi Penelitian, Mandar Maju, Bandung.

Sekaran, Uma. 2013. Metodelogi Penelitian Untuk Bisnis. Salemba Empat, Jakarta.

Siahan, Marihot P. 2005. Pajak Daerah dan Restribusi Daerah. Jakarta: PT Raja Grafindo Persada

Sofyan, Amirullah. 2016. Analisis Efektivitas dan Kontribusi Pajak Kenderaan Bermotor Terhadap Pendapatan Asli Provinsi Sulawesi Barat.

Suandy, Erly.2011. Hukum Pajak. Edisi 5. Salemba Empat, Jakarta.

Sugiono. 2013. Statistik Untuk Penelitian. CV Alfabeta. Bandung.
Tarigan, K Wanta. 2013. Jurnal Emba ISSN 23031174 Vol.1 3 juni 2013, hal 282-291. Analisis Efektivitas dan Kontribusi PBB terhadap Penerimaan Pajak Di KPP Pratam Manado, Universitas Sam Ratulangi.

Undang-Undang No 28 Tahun 2009 Tentang Pajak Daerah dan Retribusi Daerah.

Undang-Undang No. 23 Tahun 20014 Tentang Pemerintah Daerah

Undang-Undang No.33 Tahun 2004 Tentang Perimbangan Keuangan antara Pemerintah Pusat dan Pemerintah Daerah.

Velayati, M Rizkika, at al. 2013. Analisis Efektivitas dan Kontribusi tindakan penagihan pajak aktif dengan suarat teguran dan surat paksa sebagai upaya pencairan tunggakan pajak. Studi pada kantor pelayanan pajak pratama baru tahun 2010-2012. Universitas Brawijaya. Skripsi. 